\title{
KAJIAN EXPERIENTIAL MARKETING DALAM MEMBENTUK CITRA PARIWISATA KOTA BANDUNG
}

\author{
Mohamad Hadi Prasetyo ${ }^{1}$, Terra Saptina Maulani ${ }^{2}$ \\ ${ }^{1,2}$ Sekolah Tinggi Ilmu Ekonomi Ekuitas, Bandung, Indonesia \\ hadi.p@ekuitas.ac.id ${ }^{1}$,terra.saptina@ekuitas.ac.id ${ }^{2}$
}

\begin{abstract}
The economic development today is very fast, especially in the tourism services sector. Bandung is a leading tourist destination of West Java province. The high number of visits to tourism destinations will have a positive impact on local revenue. Therefore the availability of infrastructure supporting facilities of tourism becomes important to increase tourist visits, so that Bandung remains active and supported by an effective promotional media. Forming a positive image of tourism destinations to tourists is not only formed from marketing communications strategy, but from various experiences felt by tourists. $t$. The method in this research is descriptive verificative, with data collection tool in the form of questionnaire. The sample in this research are domestic and foreign tourists who visited the city of Bandung as many as 400 respondents. The results in this research show that there is influence of Experiential Marketing in shaping the image of Bandung city tourism by $86.3 \%$ and the rest influenced by other factors outside the model.
\end{abstract}

Keywords: experiential marketing; image

\begin{abstract}
Abstrak
Perkembangan perekonomian saat ini sangat pesat, khususnya pada sektor jasa pariwisata. Bandung yang merupakan destinasi wisata unggulan provinsi Jawa Barat. Tingginya jumlah kunjungan pada destinasi pariwisata akan memiliki dampak positif terhadap pendapatan daerah. Maka dari itu ketersediaan sarana prasarana pendukung pariwisata menjadi penting untuk meningkatkan kunjungan wisata, sehingga kota Bandung tetap aktraktif dan didukung dengan media promosi yang efektif. Membentuk citra yang positif kepada wisatawan tidak hanya dibentuk dari strategi komunikasi pemasaran, akan tetapi dari berbagai pengalaman yang dirasakan oleh wisatawan. Metode penelitian dalam penelitian ini adalah deskriptif verifikatif, dengan alat pengumpulan data berupa kuisioner. Sampel dalam penelitian ini adalah wisatawan domestik dan asing yang mengunjungi kota Bandung sebanyak 400 orang responden. Hasil dalam penelitian ini menunjukan bahwa terdapat pengaruh Experiential Marketing dalam membentuk citra pariwisata kota Bandung sebesar $86,3 \%$ dan sisanya dipengaruhi oleh faktor lain di luar model.
\end{abstract}

Kata Kunci: experiential marketing; citra

Corresponding author: Email : hadi.p@ekuitas.ac.id

History of article : Received: Desember 2017, Revised : Februari 2018, Published: April 2018 


\section{PENDAHULUAN}

Perkembangan ekonomi saat ini sudah sangat pesat dibandingkan dengan beberapa dekade yang lalu dimana menekankan pada pendekatan yang berorientasi pada pertukaran barang saja, sekarang telah berevolusi tidak hanya pertukaran barang saja akan tetapi lebih menekankan pada jasa. Fitzimions dan Fitzimons (2011) menyatakan bahwa aktivitas ekonomi yang paling puncak adalah quinary extending human potensial, yang aktivitasnya berupa pendidikan, kesehatan, penelitian, seni, dan rekresi pariwisata yang melibatkan potensi manusia sebagai penyedia jasa. Perkembangan industri jasa yang sangat pesat adalah jasa pariwisata saat ini telah menjadi salah satu roda perekonomian dunia yang terbukti mampu memberikan kontribusi terhadapkemakmuran suatu wilayah. Senada dengan yang diungkapkan WTO (World Tourism Organization), pariwisata merupakan bagian yang tidak terpisahkan dari kehidupan manusia terutama menyangkut kegiatan sosial dan ekonomi. Berdasarkan Undang Undang No. 10 tahun 2009 tentang Kepariwistaan menyatakan bahwa Kepariwisataan berfungsi memenuhi kebutuhan jasmani, rohani, dan intelektual setiap wisatawan dengan rekreasi dan perjalanan serta meningkatkan pendapatan negara untuk mewujudkan kesejahteraan rakyat, serta pada pembangunannya tidak hanya berdasarkan pada perencanaan nasional saja, tetapi mengacu pada perencanaan Provinsi dan Kota/ Kabupaten. Dengan adanya kebijakan otonomi daerah menuntut kemandirian daerah dalam mengelola aset aset daerah yang dimilikinya untuk memajukan sektor pariwisatanya, karena setiap wilayah di Indonesia memiliki karakteristik berbeda- beda baik dari segi demografis, geografis maupun budayanya, hal tersebut menjadi potensi sektor kepariwisataan daerah, yang pada akhirnya dapat meningkatkan Pendapatan Asli Daerah (PAD) sehingga terciptanya kesejahteraan masyarakat. Seperti tertuang dalam paparan Deputi Bidang Ekonomi Badan Perencanaan Pembangunan Nasional Kementrian Perencanaan Pembangunan Nasional dalam bidang Pembangunan Pariwisata 2015-2019 yaitu peningkatan daya saing pariwisata dengan dua sasaran. Sasaran pertama mengarah pada sasaran pertumbuhan yaitu pertumbuhan wisatawan (nusantara maupun mancanegara), devisa negara, dan pertumbuhan PDB, kedua ialah meningkatnya usaha lokal dalam industri pariwisata dan meningkatnya jumlah tenaga kerja lokal yang tersertifikasi.

Provinsi Jawa Barat merupakan wilayah dengan pusat kegiatan ekonomi terdapat di Kota Bandung sebagai ibu kota provinsi. Tingginya kunjungan ke Jawa Barat di ikuti juga dengan tingginya kunjungan ke Kota Bandung, dapat dilihat pada gambar berikut:

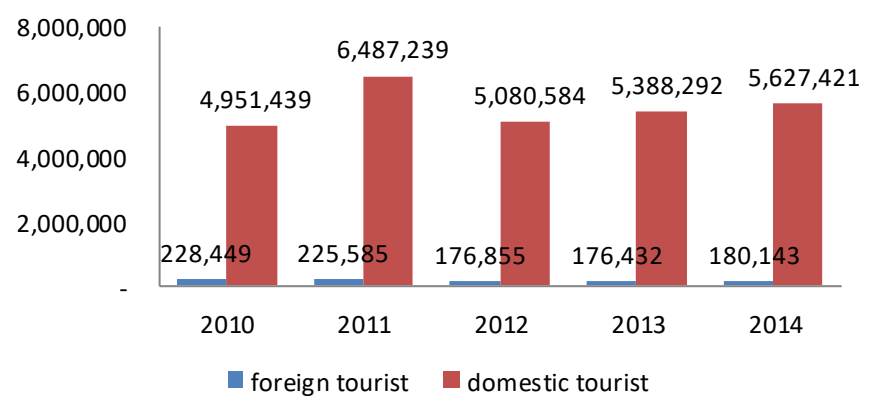

Sumber: Dinas Kebudayaan dan Pariwisata, 2015

Gambar 1. Jumlah Kunjungan

Dari data di atas, Kota Bandung yang merupakan salah satu destinasi wisata unggulan provinsi Jawa Barat dengan tingginnya jumlah kunjungan berdampak pada pendapatan daerah. Berdasarkan data Rencana Pembangunan Jangka Menengah Daerah (RPJMD) Kota Bandung 2014 -2018, struktur ekonomi kota Bandung paling tinggi berasal dari sektor tersier salah satunya pariwisata sebesar 40,8\%, kontribusi yang cukup signifikan terhadap perekonomian. Pengembangan sektor pariwisata di Kota Bandung diarahkan menjadi konsep MICE City. Hal tersebut sejalan dengan fungsi Kota Bandung yang merupakan ibu kota Jawa Barat dan kota jasa, produk pariwisata MICE (meeting, incentive, conference, exhibition).

Berdasarkan Tabel 1 dapat dilihat terdapat cluster wisata yang banyak diminati dan terdapat beberapa cluster wisata yang kurang diminati. Adapun terobosan saat ini dalam ketersediaan sarana prasarana 
pendukung pariwisata menjadi salah satu perhatian penting untuk meningkatkan kunjungan wisata, diantaranya dapat melalui bus/tram wisata, sepeda wisata serta pengadaan festival dan destinasi wisata baru, agar Kota Bandung tetap aktraktif dan didukung dengan media promosi yang efektif.

Tabel 1. Kawasan Paling diminati

\begin{tabular}{|c|c|c|}
\hline No & Kawasan & Persentase \\
\hline 1 & $\begin{array}{l}\text { Cluster Wisata Kuliner, } \\
\text { Wisata Heritage, Pendidikan, } \\
\text { Hiburan dan Rekreasi, } \\
\text { Geowisata di Jalur ir. H. } \\
\text { Juanda (Dago)-Merdeka- } \\
\text { Riau; }\end{array}$ & $32,6 \%$ \\
\hline 2 & $\begin{array}{l}\text { Cluster Wisata Belanja di } \\
\text { Cihampelas }\end{array}$ & $24,7 \%$ \\
\hline 3 & $\begin{array}{l}\text { Cluster Wisata Hiburan, } \\
\text { Wisata Belanja, Geowisata di } \\
\text { Jalur Alun-Alun-Sudirman- } \\
\text { Otista-Gardujati-Pasirkaliki; }\end{array}$ & $15,3 \%$ \\
\hline 4 & $\begin{array}{l}\text { Cluster Wisata Sejarah dan } \\
\text { Heritage di Jalur Braga-Asia } \\
\text { Afrika-Cikapundung; }\end{array}$ & $10,5 \%$ \\
\hline 5 & $\begin{array}{l}\text { Cluster Wisata Rohani dan } \\
\text { Wisata Belanja di Jalur } \\
\text { Gegerkalong-Setiabudi; }\end{array}$ & $7,5 \%$ \\
\hline 6 & $\begin{array}{l}\text { Cluster Wisata Heritage, } \\
\text { Pendidikan, Rekreasi Alam } \\
\text { dan Buatan, Wisata } \\
\text { Konvensi, Religi di Jalur } \\
\text { Gedung Sate-Gasibu-Sabuga; }\end{array}$ & $5,8 \%$ \\
\hline 7 & $\begin{array}{l}\text { Cluster Wisata Kuliner di } \\
\text { Burangrang }\end{array}$ & $2,1 \%$ \\
\hline 8 & $\begin{array}{l}\text { Cluster Wisata Rekreasi } \\
\text { Alam, Wisata Budaya, } \\
\text { Wisata Industri Kerajinan di } \\
\text { Jalur Dago Utara-Punclut }\end{array}$ & $1 \%$ \\
\hline 9 & $\begin{array}{l}\text { Cluster Wisata Seni Budaya } \\
\text { Tradisional dan Industri } \\
\text { Kerajinan di Jalur Padasuka- } \\
\text { Suci; }\end{array}$ & $0,3 \%$ \\
\hline 10 & $\begin{array}{l}\text { Cluster Wisata Belanja dan } \\
\text { Wisata Industri Kerajinan di } \\
\text { Cibaduyut }\end{array}$ & $0,2 \%$ \\
\hline
\end{tabular}

Sumber : Kajian Bappeda Kota Bandung

Akan tetapi fenomena saat ini bukan hanya kota Bandung saja yang sedang mempercantik diri dengan berbagai suguhan destinasi wisatanya, tetapi kota-kota lain pun tengah melakukan hal yang sama untuk terus menarik potential market nya. Beberapa kepala daerah membuat strategi masingmasing yang dapat meningkatkan tingkat kunjungan wisatawan baik domestik maupun mancanegara. Strategi meningkatkan sisi kepariwisataan juga dapat dikembangkan untuk mengundang beberapa calon investor yang akan berinvestasi di kota tersebut ( Majalah Marketing, 2015).

Wisatawan yang berkunjung ke kota Bandung akan mendapatkan pengalaman tersendiri dalam liburannya. Pengalaman tersebut mentukan apakah wisatawan akan memilih kembali kota Bandung sebagai salah satu tempat destinasi wisata atau tidak, hal tesebut dapat dipengaruhi oleh kepuasannya. Senada dengan Kotler, dkk (2010) mengemukakan bahwa tujuan dari suatu bisnis adalah menciptakan, dan mempertahankan kepuasan profitable customers, pelanggan harus dipikat dan dipertahankan pada saat pertama kali bertemu. Banyak hal yang dapat membangkitkan pengalaman mereka dalam berpariwisata, seperti suasana kota, budaya, keramahan warga dan lainnya. Tentu hal seperti itu sudah dipikirkan oleh kepala daerah masing-masing.

Membentuk citra yang positif kepada wisatawan tidak hanya dibentuk dari strategi komunikasi pemasaran, tetapi dapat berasal dari pengalaman yang dialami oleh wisatawan ketika mengunjungi objek wisata. Dimulai dari semakin bertambahnya jumlah wisatawan dan juga semakin terkenalnya kota Bandung di mata masyarakat Indonesia dan masyarakat dunia pada umumnya. Dalam rangka menarik pengunjung adanya upaya khusus untuk menciptakan pengalaman yang berbeda, pengalaman yang tidak ditawarkan destinasi lain sehingga menjadi suatu keungulan karena pengalaman merupakan komponen utama dalam membentuk respon, persepsi, dan perasaan yang beda tiap konsumen (William, 2006). Walaupun Kota Bandung sudah menjadi destinasi wisata unggulan baik lingkungan Jawa Barat maupun Nusantara, namun terdapat beberapa permasalahan yang dirasakan mengganggu wisatawan sehingga mengurangi kepuasan kunjungan di Kota Bandung, diantaranya ialah kemacetan, ketertiban pengendara kendaraan bermotor, pedagang kaki lima, kebersihan, kondisi jalan yang berlubang, dan pengemis. Dari berbagai permasalahan tersebut, menarik untuk diteliti apakah pengalaman positif berwisata yang 
dirasakan oleh wisatawan yang berkunjung ke Kota Bandung akan luntur dan mengakibatkan akan tercipta citra yang negatif pada Kota Bandung. Karena sebagian besar Pendapatan Asli Daerah Kota Bandung Berasal dari sektor pariwisata.

Dengan membuat kajian tentang pengalaman yang dirasakan oleh wisatawan akan membentuk citra pariwisata Kota Bandung, maka akan menghasilkan model yang diharapkan dapat dituangkan menjadi kebijakan untuk meningkatkan citra Kota Bandung. Hal ini senada dengan arah kebijakan yang dibuat oleh Kementrian Pembangunan Nasional dalam bidang Pembangunan Pariwisata pada poin 2 yaitu tentang pembangunan destnasi wisata dengan meningkatkan citra kepariwisataan. Dengan kata lain, kebijakan yang dikeluarkan oleh Kota Bandung akan sejalan dengan kebijakan yang tarafnya nasional yaitu yang dikeluarkan oleh kementrian pembangunan nasional dalam bidang pembangunan pariwisata.

\section{KAJIAN PUSTAKA \\ Experiential Marketing}

Experiential marketing adalah upaya pemasaran yang menggunakan peristiwa pribadi yang terjadi sebagai tanggapan atas beberapa jenis stimulus sebagai penghubung antara produk dengan pelanggan (Kustini, 2007). Experiential marketing adalah kemampuan produk untuk menawarkan pengalaman emosi hingga menyentuh hati dan perasaan konsumen (Winahyuningsih, et al, 2011). Dari kedua pengertian diatas, secara umum disimpulkan bahwa experiential marketing merupakan straegi yang menyentuh sisi psikologis dari konsumen selain dari konsumen merasakan manfat dari inti produk itu sendiri. Dalam kondisi saat ini banyak digunakan suatu bentuk pemasaran yang mencoba menganalisis konsumen dengan menyentuh sisi psikologis dalam menganalisis perilaku konsumen yaitu experiential marketing. Produk, baik barang ataupun jasa haruslah memiliki daya tarik. Baik dari sisi benefit yang terkandung dalam produk tersebut maupun faktor pendukungnya. Menciptakan pengalaman positif bagi konsumen diperlukan untuk menciptakan sensasi tak terlupakan juga deferensiasi suatu produk yang dapat menciptakan kepuasaan (Sahiraliani, 2013).

Pengalaman yang ada dalam pada sebuah produk, memungkinkan konsumen menilai tinggi rendahnya nilai yang didapat dari penggunaan produk, semakin tinggi nilainya maka semakin puas konsumen mengonsumsi produk tersebut dan begitu pula sebaliknya (Liulianto, 2013). Dalam pendekatan ini, pemasar menciptakan produk atau jasa dengan menyentuh panca indra konsumen, menyentuh hati, dan merangsang pikiran konsumen, karena apabila produk dapat menyentuh nilai emosional pelanggan secara positif maka dapat menjadi memorable experience (Putri \& Astuti, 2010). Kelima dimensi experiential marketing disebut oleh Bernd Schmitt merupakan konsep Strategic experiential modules (SEMs), dapat dijelaskan sebagai berikut (Winahyuningsih, et al, 2011) :

1. Sense (panca indera), mengacu pada kelima panca indera manusia dimana tujuan umumnya ialah untuk menghasilkan kenikmatan estetika (kegembiraaan, kepuasan, keindahan) konsumen.

2. Feel (perasaan), suatu strategi dan implementasi yang bermaksud mempengaruhi pasar atas produk melalui media experience providers, serta untuk dapat berhasil harus terlebih dahulu dipahami bagaimana cara menciptakan suatu perasaan pada saat proses mengonsumsi produk. Hal tersebut bisa didukung oleh iklan, kemasan, merek, dan desain. perasaan dan emosi konsumen dengan tujuan mempengaruhi pengalaman yang dimulai dari suasana hati yang lembut sampai dengan emosi yang kuat terhadap kesenangan dan kebanggaan. Perasaan di sini sangatlah berbeda dengan kesan sensorik karena hal ini berkaitan dengan suasana hati dan emosi jiwa seseorang

3. Think (pemikiran), bertujuan untuk mendorong konsumen untuk terlibat dalam suatu pemikiran kreatif yang luas dan berdampak pada perubahan image produk. Dimana peran pentingnya ialah merubah asumsi ekpektasi konsumen. Dengan berpikir dapat merangsang kemampuan intelektual dan kreativitas seseorang.

4. Act (tindakan), act marketing yang didisain untuk menciptakan experience konsumen yang berkaitan dengan kondisi fisik, pola perilaku jangka panjang dan gaya hidup sebagai 
manifestasi dari interaksi dengan orang lain. Act adalah salah satu cara untuk membentuk persepsi pelanggan terhadap produk dan jasa yang bersangkutan. Hal ini berhubungan dengan bagaimana membuat orang berbuat sesuatu dan mengekspresikan gaya hidupnya (lifestyle \& physical body).

5. Relate (hubungan), mengembangkan suatu experience diluar sensasi personal, perasaan, logika dan tindakan dengan menghubungkan individu pada konteks sosial budaya yang lebih luas. Related adalah salah satu cara membentuk atau menciptakan komunitas pelanggan dengan komunikasi dan penggabungan aspek sebelumnnya. Related berkaitan dengan budaya seseorang dan kelompok referensinya yang dapat menciptakan identitas sosial (generasi, kebangsaan, etnis). Relate menggabungkan aspek sense, feel, think, dan act dengan maksud untuk mengkaitkan individu dengan apa yang diluar dirinya dan mengimplementasikan hubungan antara other people dan other social group sehingga mereka bisa merasa bangga dan diterima di komunitasnya. Relate dapat memberikan pengaruh yang positif atau negatif terhadap kepuasan konsumen. Ketika relate mampu membuat konsumen masuk dalam komunitas serta merasa bangga dan diterima maka akan memberikan pengaruh positif terhadap kepuasan konsumen tetapi ketika relate tidak berhasil meningkatkan individu dengan apa yang ada di luar dirinya maka konsumen tersebut tidak akan mungkin puas dan memberikan dampak yang negatif.

Maka, dapat dikatakan bahwa experiential marketing merujuk pada pengalaman nyata pelanggan terhadap brand/product/service untuk meningkatkan penjualan dan brand image yang diharapkan yang nantinya bisa menimbulkan kepuasan konsumen dan berujung pada loyalitas konsumen terhadap produk maupun perusahaan (Dimyati, 2014). Melalui experiental marketing, pemasar berusaha untuk mengerti, berinteraksi dengan konsumen dan berempati terhadap kebutuhan mereka (Kusumawati, 2011).

\section{Brand Image (Citra)}

Citra dapat didefinisikan sebagai perangkat keyakinan, gagasan dan kesan yang dianut seseorang tentang sebuah obyek di mana sikap dan tindakan seseorang terhadap suatu obyek akan sangat bergantung pada citra tersebut (Sulaksana, 2007). Arslan \& Altuna (2010) menyebutkan brand merupakan hal yang paling penting dan juga bisa menjadi aset terpenting bagi pemilik perusahaan. Dari hal inilah perusahaan bisa mendapatkan citra dari suatu merek. Citra merek yang kuat dapat memberikan sejumlah keunggulan, kapabilitas yang unik yang sulit ditiru, loyalitas pelanggan dan pembelian ulang yang lebih besar, dan masih banyak lagi input positif yang bisa diterima perusahaan (Chandra dalam Faqih, 2008). Sementara itu, brand image dapat dianggap sebagai jenis asosiasi yang muncul dibenak konsumen ketika mengingat sebuah merek tertentu. Hal itu juga bergantung pada "style" pada produk tersebut.Dalam hal tujuan wisata atau bisa dikatakan sebuah lokasi, menurut Primasari, dkk (2013) suatu lokasi atau tempat dapat diberi merek yang secara relatif pasti berasal dari nama sebenarnya dari lokasi tersebut. Dalam penanganan sebuah brand terutama brand untuk lokasi atau kota ada beberapa proses yang harus dilakukan agar pesan yang ditujukan dapat diterima oleh khalayak dengan baik sehingga tujuan dari pemberian merek suatu kota tersebut dapat tercapai dengan sempurna (Primasari, 2013). Citra tidak dapat ditanamkan dalam pikiran masyarakat dalam semalam atau disebarkan melalui satu media saja. Sebaliknya citra itu harus disampaikan melalui tiap sarana komunikasi yang tersedia dan disebarkan secara terus-menerus. (Sondoh, et all., 2007).

Citra destinasi sering juga dikatakan sebagai merek suatu tempat (destination brand) dan lebih jauh dikemukakan bahwa perilaku positif dapat digunakan untuk megukur kekuatan afeksi suatu tujuan wisata (Andalas \& Kartika, 2015). Citra tujuan wisata menentukan peran fundamental dalam keberhasilan suatu daerah tujuan wisata. Hal ini karena citra tujuan wisata memberi efek multidimensi baik masyarakat lokal maupun wisatawan (Andalas \& Kartika, 2015). Citra dapat didefinisikan sebagai sekumpulan kepercayaan, ide-ide dan kesan orang terhadap suatu organisasi (Kotler, dkk, 2009). Sementara itu semua sikap bersumber pada informasi dan pengetahuan yang dimiliki oleh konsumen. Efek kognitif dari komunikasi sangat mempengaruhi proses pembentukan 
citra.

Citra sebuah merek adalah seperangkat asosiasi unik yang ingin diciptakan atau dipelihara para pemegang merek (Surachman, 2008). Asosiasi dari suatu merek (citra merek) dapat menentukan pengaruh terhadap keinginan konsumen untuk membeli (Febriani, 2008). Dalam hal ini diharapkan mampu untuk memengaruhi keinginan konsumen untuk melakukan tujuan wisatanya ke Kota Bandung. Ada empat faktor penting dari citra merek (Febriani; 2008) :

1. Recognition; tingkatan atau level dari kesadaran merek. Menggambarkan keberadaan merek dalam pikiran konsumen dan mempengaruhi persepsi serta tingkah laku.

2. Reputation; status yang dibentuk oleh perusahaan itu sendiri dengan meningkatkan kualitas keseluruhan dari produk tersebut.

3. Affinity; merupakan emotional relationship yang timbul antara sebuah merek dengan konsumennya. Disejajarkan dengan asosiasi positif dan menjadi pijakan konsumen dalam keputusan pembelian serta loyalitas terhadap merek tersebut.

4. Domain; menyangkut seberapa luas jangkauan yang secara potensial didapat suatu merek yang berkaitan dengan scope produk itu sendiri.

\section{METODE PENELITIAN}

Metode dalam penelitian ini adalah deskriptif dan verifikatif. Pengumpulan data menggunakan kuisioner yang disebarkan langsung pada responden. Populasi dalam penelitian ini adalah wisatawan domestik dan asing yang mengunjungi kota Bandung selama satu tahun terakhir, berdasarkan data Dinas Kebudayaan dan Pariwisata Kota Bandung, jumlah wisatawan pada tahun 2014 adalah sebesar 5.807.567 orang dengan rincian Wisman: 180.143 orang dan Winus: 5.627.421 orang. Berikut jumlah sampel yang digunakan dalam penelitian ini berdasarkan teknik slovin:

Tabel 2. Jumlah sampel

\begin{tabular}{llcc}
\hline No & Wisatawan & Jumlah Sampel \\
\hline 1 & $\begin{array}{l}\text { Wisman } \\
\text { Mancanegara) }\end{array}$ & (Wisatawan \\
& & \\
\hline 2 & Winus (Wisatawan Nusantara) & 388 \\
\hline & Jumlah Sampel & 400
\end{tabular}

Sumber: Data Primer Diolah, 2017
Metode pengumpulan data pada penelitian ini adalah dengan wawancara, observasi, studi kepustakaan dan penyebaran kuisioner. Untuk mengetahui tingkat kevalidan alat uji telah dilakukan uji validitas. Serta untuk mengetahui tingkat keandalan alat uji telah dilakukan uji reliabilitas. Untuk mengetahui bagaimana Experiential Marketing dan Image berdasarkan prespektif wisatawan menggunakan analisis deskriptif, dengan menentukan terlebih dahulu kriterianya berdasarkan range interval dengan mengacu kepada rumus statistik sebagai berikut,

$$
c=\frac{\mathrm{X}_{\mathrm{n}}-\mathrm{X}_{1}}{\mathrm{~K}} \text { Supranto (2008) }
$$

$\mathrm{c}=$ perkiraan besarnya (class width, class size, class length)

$\mathrm{k}=$ banyaknya kelas

$\mathrm{X}_{\mathrm{n}}=$ nilai observasi terbesar

$\mathrm{X}_{1}=$ nilai obervasi terkecil

Sedangkan pada analisis verifikatif untuk mengetahui seberapa besar keeratan hubungan dan pengaruh Experiential Marketing terhadap Image dengan menggunakan analisis regresi sederhana.

\section{HASIL DAN PEMBAHASAN}

Hasil uji validitas data pada penelitian ini menunjukkan koefisien korelasi dari seluruh butir pertanyaan memiliki koefisien korelasi Product Moment Pearson (rxy) $>\mathrm{r}$ tabel $(0,3)$. Dengan demikian seluruh butir pertanyaan yang ada pada instrument penelitian dapat dinyatakan valid atau sahih. Sedangkan untuk uji reliabilitas data diketahui nilai koefisien Cronbach Alpha pada masingmasing variabel; nilai koefisien Cronbach Alpha pada variabel Experiential Marketing adalah 0,952; sedangkan nilai koefisien Cronbach Alpha pada variabel Brand Image adalah 0,883. Maka dari itu uji relibilitas pada studi ini reliabel, apabila hasil koefisien Alpha lebih kecil dari taraf signifikansi $60 \%$ atau 0,6 maka kuesioner tersebut tidak reliable. Secara umum, keandalan kurang dari 0,60 dianggap buruk, keandalan dalam kisaran 0,70 bisa diterima, dan lebih dari 0,80 adalah baik 
(Sekaran, 2003).

Secara demografi, responden penelitian ini terdiri dari $51,3 \%$ atau 205 orang berjenis kelamin pria dan 48,7\% atau 195 orang berjenis kelamin wanita. Para wisatawan yang datang berkunjung, ada yang datang sendiri dan juga ada yang datang dengan keluarga maupun teman. Mereka datang untuk rekreasi tidak hanya sendiri tetapi bersama keluarga, teman ataupun lainnya mayoritas pengunjung datang bersama keluarga dengan persentase sebesar 43,3\% atau sekitar 172 orang. Responden yang datang sendiri sebesar 25,3\% atau sekitar 101 orang dan yang datang bersama teman sebesar $22,7 \%$ atau sekitar 92 orang. Serta lainnya sebesar $8,7 \%$ atau sekitar 35 orang, yaitu wisatawan yang bereksreasi bersama rombongan sekolah atau intansi / organisasi tempat bekerja.

Pariwisata merupakan aspek yang sangat penting dalam peningkatan perekonomian pada suatu daerah. Setiap daerah tentu harus bisa mengembangkan tempat wisata tersebut menjadi unik dan memiliki ciri khas, sehingga wisatawan yang berkunjung mendapatkan pengalaman yang baru dan mengesankan. Untuk mendapatka hal tersebut, pihak pengelolaan pariwisata harus melakukan upaya untuk meningkatkan pengalaman yang berkesan pada setiap wisatawan yang berkunjung, sehingga dengan pengalaman yang mengesankan dapat membentuk citra yang positif pada objek pariwisata disuatu daerah. Untuk melihat hasil terkait Experiential marketing yang dirasakan oleh wisatawan yang berkunjung ke Kota Bandung, dapat dilihat dalam Tabel 3 . Kemudian nilai pada Tabel 3 diinterpretasikan dengan standar penilaian pada Tabel 4.
Tabel 3. Skor Experiental Marketing

\begin{tabular}{|c|c|}
\hline PERTANYAAN & Rata \\
\hline Sense & Score \\
\hline Tingkat kestrategisan lokasi objek wisata & 3,83 \\
\hline Tingkat keterawatan objek wisata & 3,58 \\
\hline $\begin{array}{l}\text { Tingkat kemudahan akses transportasi menuju } \\
\text { objek wisata }\end{array}$ & 3,40 \\
\hline $\begin{array}{l}\text { Penilaian saya terhadap kebersihan objek } \\
\text { wisata }\end{array}$ & 3,49 \\
\hline Tingkat kenyamanan objek wisata & 3,68 \\
\hline $\begin{array}{l}\text { Tingkat keunikan bangunan/ desain letak } \\
\text { objek wisata }\end{array}$ & 3,89 \\
\hline $\begin{array}{l}\text { Penilaian saya terhadap fasilitas penunjang } \\
\text { lainnya seperti toilet, parkir }\end{array}$ & 3,28 \\
\hline $\begin{array}{l}\text { Penilaian saya mengenai keindahan objek } \\
\text { wisata di kota Bandung }\end{array}$ & 4,03 \\
\hline \multicolumn{2}{|l|}{ Feel } \\
\hline $\begin{array}{l}\text { Setelah mengunjungi objek wisata di Bandung } \\
\text { saya semakin tertarik }\end{array}$ & 3,99 \\
\hline $\begin{array}{l}\text { Saya gembira/ senang mengunjungi objek } \\
\text { wisata di kota Bandung }\end{array}$ & 3,99 \\
\hline $\begin{array}{l}\text { Saya kagum terhadap objek wisata di Kota } \\
\text { Bandung }\end{array}$ & 3,95 \\
\hline $\begin{array}{l}\text { Apakah saya bangga mengunjungi destinasi } \\
\text { wisata di Kota Bandung }\end{array}$ & 3,96 \\
\hline \multicolumn{2}{|l|}{ Think } \\
\hline $\begin{array}{l}\text { Mendatangi objek wisata di Bandung } \\
\text { merupakan pengalaman yang unik }\end{array}$ & 3,85 \\
\hline $\begin{array}{l}\text { Mendatangi wisata di Bandung menyajikan } \\
\text { pengalaman yang tidak dapat dilupakan }\end{array}$ & 3,82 \\
\hline \multicolumn{2}{|l|}{ Act } \\
\hline $\begin{array}{l}\text { Setelah mengunjungi salah satu objek wisata } \\
\text { di Bandung membuat saya ingin lebih tahu } \\
\text { lebih banyak tentang objek wisata lainnya }\end{array}$ & 3,97 \\
\hline $\begin{array}{l}\text { Secara pribadi pengalaman yang telah } \\
\text { diperoleh membuat semakin tertarik }\end{array}$ & 3,94 \\
\hline \multicolumn{2}{|l|}{ Relate } \\
\hline $\begin{array}{l}\text { Tingkat kemudahan mendapatkan informasi } \\
\text { dari petugas di kawasan objek wisata }\end{array}$ & 3,68 \\
\hline $\begin{array}{l}\text { Tingkat keramahan petugas di kawasan objek } \\
\text { wisata }\end{array}$ & 3,66 \\
\hline $\begin{array}{l}\text { Tingkat kesigapan petugas di kawasan objek } \\
\text { wisata }\end{array}$ & 3,55 \\
\hline $\begin{array}{l}\text { Penilaian saya mengenai tingkat keramahan } \\
\text { masyarakat kota Bandung }\end{array}$ & 4,00 \\
\hline $\begin{array}{l}\text { Penilaian tingkat kreatifitas masyarakat/ } \\
\text { komunitas di Kota Bandung }\end{array}$ & 4,21 \\
\hline Rata rata Skor / Kategori & 3,84 \\
\hline Maximum Skor & 4,21 \\
\hline Minimum Score & 3,28 \\
\hline
\end{tabular}


Tabel 4 Standar Skor Penilaian Experiental Marketing

\begin{tabular}{|l|c|l|}
\hline Skor maksimal & $\begin{array}{l}5 \times 21 \quad \text { x } 400= \\
42.000\end{array}$ & \\
\hline Skor minimal & $1 \times 21$ x $400=8.400$ & \\
\hline Range & $8.400<15.120$ & \\
& $15.120 \geq 21.840$ & \\
& $21.840<28.560$ & \\
& $28.560 \geq 35.280$ & \\
& $35.280<42.000$ & \\
\hline Rata -Rata & $1 \quad<1,8$ & Sangat \\
& $1,8 \geq 2,6$ & Buruk \\
& $2,6<3,4$ & Buruk \\
& $3,4 \geq 4,2$ & Cukup \\
& $4,2<5$ & Baik \\
& & Sangat Baik \\
\hline
\end{tabular}

Secara keseluruhan, dari hasil yang tertera dalam tabel di atas, maka experiential marketing yang dirasakan oleh wisatawan dapat dikategorikan Baik. Terbukti dalam hasil yang didapat rata-rata/kriteria pada poin 3,84 atau dengan jumlah total skor sebesar 31.888. Dimana angka tersebut masuk dalam rentang $28.560 \geq 35.230$ atau $3,4 \geq 4,2$ yang dikategorikan Baik. Nilai maximum sebesar 4,21 terdapat pada subvariabel relate dengan indikator penilaian wisatawan mengenai kreatifitas masyarakat dan komunitas komunitas yang ada di kota Bandung dinilai sangat kreatif. Sedangkan nilai minimum sebesar 3,28 terdapat pada subvariabel sense dengan indikator penilaian wisatawan megenai fasilitas umum yang dirasakannya seperti toilet, parkir dan fasilitas penunjang lainnya dinilai cukup.

Dalam hal ini terlihat bahwa wisatawan (domestik maupun mancanegara) yang dapat dikatakan sebagai konsumen dari tempat tujuan wisata yang ada di Kota Bandung memiliki pengalaman yang baik. Hal tersebut bisa saja karena pada saat mereka berkunjung mendapat pengalaman dalam hal tourism yang kemungkinan belum mereka dapati sebelumnya. Peningkatan experiential marketing yang didapat oleh konsumen (wisatawan) bisa terjadi dari adanya pelaksanaan konsep differentiation yang diusung oleh pengelola tujuan wisata. Akhirnya wisatawan mendapati suatu pengalaman berwisata yang belum mereka dapatkan di tempat lainnya selain dalam tempat tujuan wisata yang ada di Kota Bandung. Hal ini berpengaruh positif dalam peningkatan kegiatan pariwisata, karena dimungkinkan bahwa strategi yang dilakukan oleh tempat wisata berjalan dengan baik.

Dalam menganalisis Brand Image yang terjadi di kalangan wisatawan untuk tujuan wisata di Kota Bandung, akan mengacu pada tabel berkut:

Tabel 5. Kategori Jawaban Brand Image

\begin{tabular}{|c|c|}
\hline PERTANYAAN & Rata \\
\hline Reputation & Score \\
\hline $\begin{array}{l}\text { Tingkat pengetahuan terhadap objek- objek } \\
\text { wisata di Kota Bandung }\end{array}$ & 3,48 \\
\hline $\begin{array}{l}\text { Tingkat kemudahan mengingat nama objek } \\
\text { wisata }\end{array}$ & 3,68 \\
\hline $\begin{array}{l}\text { Tingkat kemudahan mengingat logo objek } \\
\text { wisata }\end{array}$ & 3,26 \\
\hline \multicolumn{2}{|l|}{ Recognition } \\
\hline $\begin{array}{l}\text { Tingkat intensitas (seberapa sering) } \\
\text { mendengar nama dari objek wisata di Kota } \\
\text { Bandung }\end{array}$ & 3,77 \\
\hline $\begin{array}{l}\text { Tingkat keterkenalan objek wisata di Kota } \\
\text { Bandung }\end{array}$ & 3,95 \\
\hline $\begin{array}{l}\text { Kesan mengunjungi destinasi wisata di kota } \\
\text { Bandung }\end{array}$ & 3,96 \\
\hline $\begin{array}{l}\text { Destinasi wisata di Kota Bandung } \\
\text { menyenangkan }\end{array}$ & 4,05 \\
\hline \multicolumn{2}{|l|}{ Affinity } \\
\hline Tingkat ketertarikan mengunjungi kembali & 3,99 \\
\hline $\begin{array}{l}\text { saya akan merekomendasikan berbagai objek } \\
\text { wisata di Bandung sebagai alternatif tempat } \\
\text { tujuan wisata kepada orang lain }\end{array}$ & 4,12 \\
\hline \multicolumn{2}{|l|}{ Domain } \\
\hline $\begin{array}{l}\text { Kota Bandung merupakan kota dengan } \\
\text { destinasi terbaik }\end{array}$ & 3,92 \\
\hline $\begin{array}{l}\text { Kota Bandung selalu menjadi pilihan destinasi } \\
\text { wisata dibandingkan kota lain }\end{array}$ & 3,73 \\
\hline Rata rata Skor / Kategori & 3,81 \\
\hline Maximum Skor & 4,12 \\
\hline Minimum Score & 3,26 \\
\hline
\end{tabular}

Tabel 6 berikut menampilkan range interval yang digunakan dalam membuat kategori jawaban mengenai Brand Image yang berdasarkan prespektif wisatawan. Berdasarkan hasil dari perhitungan diatas terlihat bahwa hasil dari variabel Image ialah sebesar 16.760 atau dengan rata- rata skor sebesar 3,82. Hal tersebut masuk dalam kategori Baik yaitu rentang skor $14.960 \geq$ 18.480 atau pada rata-rata rentang $3.4 \geq 4.2$. Terdapat nilai maximum sebesar 4,12 pada 
subvariabel affinity, dengan indikator bahwa mereka akan merekomendasikan berbagai objek wisata di Bandung sebagai alternatif tempat tujuan wisata kepada orang lain. Sedangkan nilai minimum sebesar 3,26 terdapat pada subvariabel reputation dengan indikator kemudahan mengingat logo objek wisata yang dinilai cukup. Secara keseluruhan bahwa Image tentang tujuan wisata yang yang ada di Kota Bandung dapat dikatakan baik di kalangan para wisatawan. Maksudnya ialah para wisatwan sudah mendapat image yang baik sebelum mengunjungi dan ini dapat dijadikan alasan bahwa wisatawan ingin mengunjungi tujuan wisata yang ada di Kota Bandung.

Tabel 6.Menentukan KatagoriJawaban Brand Image

\begin{tabular}{|l|c|l|}
\hline Skor maksimal & $1111 \times 400=22.000$ & \\
\hline \multirow{2}{*}{ minimal } & $11 \times 400=4.400$ & \\
\hline Range & $4.400<7.920$ & \\
& $7.920 \geq 11.440$ & \\
& $11.440<14.960$ & \\
& $\mathbf{1 4 . 9 6 0} \geq \mathbf{1 8 . 4 8 0}$ & \\
& $18.480<22.000$ & \\
& $1,8 \geq 2,6$ & Sangat Buruk \\
& $2,6<3,4$ & Curuk \\
& $\mathbf{3 , 4} \geq \mathbf{4 , 2}$ & Baik \\
& $4,2<5$ & Sangat Baik \\
\hline
\end{tabular}

Di lain hal, image yang terbentuk oleh wisatawan pada saat mengunjungi tempat wisata diakatakan baik. Image yang terbentuk bisa saja hasil dari pengalaman wisatawan yang berkunjung sebelumnya, maupun yang dibentuk oleh dampak dari strategi promosi yang dilakukan oleh pemerintah Kota Bandung yang dibantu oleh awak media. Image yang terjadi disini sangat positif akan membantu tempat tujuan wisata mengembangkan apa yang mereka miliki. Karena image merupakan gambaran dari konsumen tentang apa yang mereka rasakan dan juga mereka lihat secara fisik. Intinya ialah apa yang mereka rasakan tersebut dapat membuat suatu hal yang positif di mata masyarakat keseluruhan. Di satu sisi image yang terbentuk dikarenakan oleh kegiatan promosi dan juga dapat terbentuk oleh pembuktian yang dirasakan oleh konsumen saat mereka mengunjungi tempat wisata. Hal tersebut juga diyakini bahwa akan memberikan dampak positif bagi kepuasan yang dirasakan oleh konsumen. Kemungkinan juga image yang terjadi ialah suatu kepercayaan konsumen yang bisa bersifat positif dan harus dipertahankan agar menjadi pemicu untuk peningkatan strategi dalam hal memasarkan tujuan wisata.

Tabel 7. Koefisien Korelasi

\begin{tabular}{ccccc}
\hline Model & $\mathrm{R}$ & R Square & $\begin{array}{c}\text { Adjusted R } \\
\text { Square }\end{array}$ & $\begin{array}{c}\text { Std. Error of the } \\
\text { Estimate }\end{array}$ \\
\hline 1 &, $929^{\mathrm{a}}$ &, 863 &, 863 & 2,260358651 \\
\hline \multicolumn{3}{l}{ Sumber: Data Primer Diolah, 2017} \\
\end{tabular}

Koefisien korelasi pada hasil di atas adalah sebesar 0,929. Menurut Sugiyono (2013:184) jika R mendekati angka 1, maka hal tersebut menunjukkan adanya hubungan yang sangat kuat. Artinya, bahwa nilai $\mathrm{R}$ yang didapat sebesar 0,929 hubungan ini menunjukan bahwa Experiential Marketing mempunyai hubungan yang sangat kuat dalam membentuk citra pariwisata di Kota Bandung. Pengalaman menjadi faktor penentu dalam pembentukan persepsi akan sesuatu hal. Seperti dalam konteks pariwisata yang dibahas dalam penelitian ini. Saat wisatawan domestik maupun asing yang berkunjung ke tempat wisata di Kota Bandung mendapatkan pengalaman mengesankan, tentu pariwisata di Kota Bandung mempunyai citra yang positif. Karena pengalaman yang mereka dapatkan akan mempengaruhi persepsi lalu ingatan mereka saat mengalami hal tertentu.

Berdasarkan tabel di atas juga diperoleh nilai $\mathrm{R}$ square $\left(\mathrm{R}^{2}\right)$ sebesar 0,863 . Artinya, bahwa besarnya pengaruh kontribusi Experiential Marketing dalam membentuk citra pariwisata di Kota Bandung sebesar $86,3 \%$, sedangkan sisanya sebesar $13,7 \%$ dipengaruhi oleh variabel atau faktor lain yang tidak diteliti dalam penelitian ini, seperti faktor promosi, harga tiket masuk pada tempat tujuan dan faktor lokasi tempat wisata. Dengan kata lain pengaruh kontribusi yang diberikan Experiential Marketing cukup besar dalam membentuk citra pariwisata di Kota Bandung, mengingat bahwa pengalaman yang dirasakan 
oleh wisatawan yang berkunjung ke Kota Bandung akan membentuk citra pariwisata di kota tersebut.

Tabel 8. Hasil Uji Regresi Sederhana

Coefficients $^{\mathrm{a}}$

maupun mancanegara) sebagai konsumen dari tempat tujuan wisata yang ada di Kota Bandung dapat dikatakan memiliki pengalaman yang baik. Banyaknya tempat wisata di Bandung sebagai faktor paling berpengaruh dalam memberikan pengalaman Unstandardized Standardized pada wisatawan yang berkunjung seperti Coefficients Coefficients wisata yang berkaitan dengan alam, wisata B $\quad$ Std. Error Beta kuliner dan juga Sig 1 (Constant) $\quad, 965 \quad, 751 \quad$ tidak 1285 terlepas dari ciri k $k^{200}$ yang dimiliki oleh

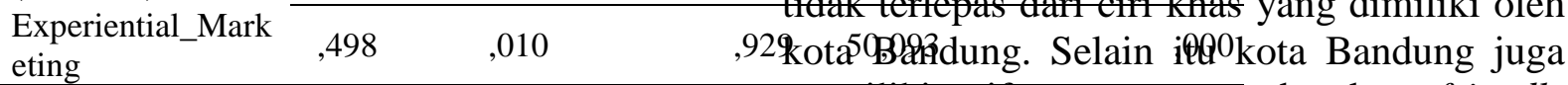

Berdasarkan hasil pengolahan data untuk regresi linier sederhana pada tabel di atas maka dapat disusun persamaan regresi linier sederhana sebagai berikut:

$$
Y=0,965+0,498 X
$$

Dari persamaan tersebut dapat diinterpretasikan apabila tidak ada nilai Experiential Marketing maka nilai Brand Image sebesar 0,965. Jika pengelola wisata ataupun pihak pemerintah tidak membuat suatu strategi pemasaran untuk meningkatkan pengalaman terhadap wisatawan yang berkunjung ke Kota Bandung, maka citra pada pariwisata akan tetap terbentuk dalam benak wisatawan. Selanjutnya koefisien regresi $\mathrm{X}$ sebesar 0,498 menyatakan bahwa setiap penambahan 1 nilai Experiential Marketing maka nilai Brand Image bertambah sebesar 0,498. Dengan kata lain, apabila pihak-pihak yang berkepentingan dalam ruang lingkup pariwisata seperti pihak pengelola wisata dan juga Pemkot Bandung membuat suatu strategi pemasaran yang dapat meningkatkan pengalaman wisatawan, maka citra pariwisata di Kota Bandung akan meningkat seiring dengan pengalaman yang dirasakan oleh wisatawan. Pengalaman yang diberikan haruslah mempunyai kesan baik dan dapat menjadi pengalaman baru yang belum pernah didapatkan di tempat wisata lainnya. Dengan begitu tentunya Kota Bandung dapat selalu diingat oleh wisatawan.

\section{KESIMPULAN DAN SARAN}

Pengalaman wisatawan (domestik memiliki sifat yang ramah dan friendly sehingga kemungkinan wisatawan yang berkunjung mendapatkan kepuasan yang turut serta mempengaruhi pengalaman yang mereka rasakan.

Image tentang tujuan wisata yang ada di Kota Bandung dapat dikatakan baik dikalangan para wisatawan. Persepsi ini terbentuk karena pengalaman yang dirasakan oleh wisatawan saat mereka berkunjung. Selain itu image juga terbentuk oleh kegiatan promosi yang dilakukan oleh setiap tempat pariwisata serta dukungan dari pemerintah dalam menguatkan image destinasi wisata di kota Bandung. Hasil ini harus terus ditingkatkan oleh semua pihak dengan tujuan untuk meningkatkan daya tarik dan jumlah wisatawan yang berkunjung ke kota Bandung. Untuk menciptakan image yang baik diperlukan waktu yang tidak sebentar selain itu semua pihak juga harus bekerjasama dan konsisten agar image pariwisata Kota Bandung tetap baik dimata masyarakat khususnya wisatawan yang berkunjung.

Pengalaman yang dirasakan oleh wisatawan sangat berhubungan dengan image yang terbentuk dalam persepsi setiap wisatawan yang berkunjung. Dapat dikatakan juga bahwa pengalaman menjadi faktor penentu dalam pembentukan persepsi akan sesuatu hal. Seperti dalam konteks pariwisata yang dibahas dalam penelitian ini. Hubungan antara pengalaman dan pembentukan image dapat terjadi saat wisatawan domestik maupun asing yang berkunjung ke tempat wisata di Kota Bandung mendapatkan pengalaman yang mengesankan dan juga hal baru yang belum pernah mereka rasakan sebelumnya. 


\section{DAFTAR PUSTAKA}

Andalas, Purwani Retno, Lucia Nurbani Kartika. (2015). Pengaruh Citra Destinasi Terhadap Minat Untuk Merekomendasikan Kunjungan Wisatawan Domestik Ke Kota Yogyakarta. Prosiding Seminar Nasional \& Call For Paper, Forum Manajemen Indonesia (FMI) $\mathrm{Ke}-7$ Dinamika Dan Peran Ilmu Manajemen Untuk Menghadapi AEC, Jakarta, 10-12 November 2015.

Arslan, F, M., \& Altuna, O, K. (2010). The Effect of Brand Extensions on Product Brand Image. Journal of Product \& Brand Management, 19(3), 170-180. School of Economic and Administrative Sciences, Marmara University, Istanbul. Retrived from Emerald Group Publishing Limited. Turkey.

Dimyati, Mochamad. (2014). Peranan Experiential Marketing Dan Kepuasan Pasien Dalam Menciptakan Loyalitas Pasien Rumah Sakit Fatimah Banyuwangi. Jurnal Ekonomi Akuntansi dan Manajemen, 13(2), ISSN: 1412-5366, Program Studi Manajemen Fakultas Ekonomi Universitas Jember.

Data Badan Perencanaan Pembangunan Nasional Kementrian Perencanaan Pembangunan Nasional

Data Bappeda Kota Bandung

Data Dinas Kebudayaan dan Pariwisata Kota Bandung

Kadjatmiko, 2002. Dinamika Sumber Ke uangan bagi Daerah dalam Rangka Otonomi Daerah. Prosiding Workshop Internasional Implementasi

Desentralisasi Fiskal sebagai Upaya Memberdayakan Daerah dalam Membiayai Pembangunan Daerah, Fakultas Ilmu Sosial dan Ilmu Politik Universitas Katolik Parahyangan, Bandung.

Faqih. (2008). Pengaruh Strategi Positioning Produk terhadap Citra Merek pada Produk Sunsilk Clean \& Fresh Shampoo. Skripsi pada Fakultas Ekonomi Jurusan Manajemen Universitas Islam Negeri (UIN) Malang: tidak diterbitkan.

Fitzsimmons, J.A and Fitzsimmons, M. J.
(2011). Service Management: Operation, Strategy, Information Technology $7^{\text {th }}$ edition. McGrow Hill. Singapore

Kotler, P., et al. (2009). Marketing Management, An Asian Perspective (5th $E d$.). Prentice Hall.Singapore.

Kotler, P., dkk. (2010). Marketing for Hospitality and Tourism $5^{\text {th }}$ edition. Pearson Prentice Hall.

Kustini. (2007). Penerapan Experiential Marketing. Jurnal Riset Ekonomi dan Bisnis, 7 (2)

Kusumawati, A., (2011). Analisis Pengaruh Experiential Marketing Terhadap Kepuasan Dan Loyalitas Pelanggan: Kasus Hypermart Malang Town Square (Matos). Jurnal Manajemen Pemasaran Modern. 3 (1). Januari-Juni 2011 ISSN 2085-0972. Jurusan Manajemen Fakultas Ekonomi Universitas Jambi.

Liulianto, Lucy. (2013). Pengaruh Experiential Marketing Dan Experiential Value Terhadap Customer Satisfaction Samasung Galaxy Note (GT-N7000) Di Surabaya. Jurnal Ilmiah Mahasiswa Universitas Surabaya. 2 (2). Jurusan Manajemen Pemasaran. Fakultas Bisnis dan Ekonomika Surabaya.

Majalah Marketing. Edisi 08/XV/Agustus (2015). PT. Dinamika Komunika Marketindo. Jakarta.

Primasari, I., dkk. (2013). City Branding Solo Sebagai Kota Wisata Budaya Jawa (Studi Deskriptif Kualitatif Tentang City Branding Solo Sebagai Kota Wisata Budaya Jawa Oleh Dinas Kebudayaan Dan Pariwisata Kota Solo). Program Studi Ilmu Komunikasi Fakultas Ilmu Sosial Dan Ilmu Politik Universitas Sebelas Maret Surakarta.

Putri, Y, A., \& Astuti, S, R, T. (2010). Analisis Pengaruh Experiential Marketing Terhadap Loyalitas Pelanggan Hotel " $X$ " Semarang. Aset, 12 (2), 191-195 ISSN 1693-928X. Semarang

Rencana Pembangunan Jangka Menengah Daerah (RPJMD) Kota Bandung 2014 2018

Sahiraliani, D. (2013). Experiential Marketing Terhadap Kepuasan Konsumen Starbucks Kota Bandung. Universitas Widyatama, 
Bandung.

Sekaran, U. (2003), Research Methods For Business: A Skill Building Aproach. John Wiley and Sons.Inc New York-USA.

Sondoh, S, L., dkk. (2007). The Effect Of Brand image On Overall Satisfaction And Loyalty Intention In The Context Of Color Cosmetic. Asian Academy of Management Journal, 12 (1), 83-107, January 2007. Malaysia.

Sulaksana, U. (2007). Integrated Marketing Communication, Teks dan Kasus. Pustaka Pelajar. Yogyakarta.

Supranto, J. (2008). Statistik Teori dan Aplikasi. Penerbit Erlangga.

Surachman, S. (2008). Dasar-Dasar Manajemen Merek, Alat Pemasaran untuk
Memenangkan Persaingan. Bayumedia Publishing. Malang.

Undang Undang No. 10 tahun 2009 tentang Kepariwistaan

Winahyuningsih, P., dkk, (2011). Analisis Faktor-Faktor Experiential Marketing Yang Mempengaruhi Keputusan Pembelian Konsumen Terhadap Sepeda Motor Yamaha Mio Di Universitas Muria Kudus. Jurnal Sosial dan Budaya, 4(2), Desember 2011. Universitas Muria Kudus.

Williams, A. (2006). Tourism and Hospitality Marketing: Fantasy, Feeling and Fun. International Journal of Contamporaty Hospitality Management, $p$ 482-495 
Journal IMAGE | Volume 7, Number 1, April 2018, page 1-12 
Journal IMAGE | Volume 7, Number 1, April 2018, page 1-12 
Journal IMAGE | Volume 7, Number 1, April 2018, page 1-12 